\title{
Social Entrepreneurship Intentions Among Business Students in Latvia
}

\author{
Velga Vevere \\ EKA University of Applied Sciences
}

\section{Edgars Cerkovskis}

EKA University of Applied Sciences

\author{
Aija Sannikova \\ EKA University of Applied Sciences \\ Гrossef http://dx.doi.org/10.5755/j01.eis.1.15.29111
}

Theoretical literature has identified a number of factors that determine social entrepreneurship intentions. Social entrepreneurs play an important role in the economic and social developments of the communities in which they operate. They are a special type of entrepreneur, driven by a variety of motives, including the alleviation of poverty, hunger or illiteracy; the improvement of human health; the reparation of social, legal or economic injustice; and the preservation of the environment for future generations. The career aspiration of social entrepreneurs can be encouraged if youths are given early educational exposure when they are young. The purpose of this study is to identify social entrepreneurship intentions among business students in Latvia. The tasks are the following: (1) to accomplish analysis of special literature; (2) to work out methodology; (3) to carry out the empirical research; (4) to work out conclusions. The empirical research involves the survey of business students, applying snowball sampling method and using 5-point Likert scale questionnaire. The results are interpreted using methods of descriptive and inferential statistics. The conclusions of the research have a practical value, as they make it possible to identify the problematic areas of business education in regard to the social entrepreneurship.

KEYWORDS: social entrepreneurship, business education, entrepreneurship intentions, career aspirations, social responsibility.

The concept and practices of social entrepreneurship play more and more significant role in the contemporary society, permeated by the social and economical inequality, that has become the most obvious during the Covid-19 crisis (unemployment, decrease of income, access to education, et.). It is not to say that socially orientated businesses are able to change the economic and social problems directly and immediately, rather - they have become one of the decisive drivers of long-term sustainability.

Discussions related to social entrepreneurship have taken place in Latvia, applied and scientific researches have been carried out, proposals have been made for the development of social entrepreneurship. Among publications we would like to mention here "Latvia on the road to social entrepreneurship" (Lešinska et al., 2012), "The development of social entrepreneurship in Latvia: the role of municipalities" (Lukjanska et al., 2017), "Social enterprises and their ecosystems in Europe. Country report LATVIA" (Līcīte, 2018), "Development of Social Entrepreneurship in

\section{Abstract}

\section{Introduction}

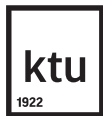

European Integration Studies No. 15 / 2021, pp. 251-259 doi.org/10.5755/j01.eis.1.15.29111 
Latvia" (Sannikova \& Brante, 2018). The legal framework and existing practices of social entrepreneurship in Latvia are described in the publication "Social entrepreneurship in Latvia: a brief overview of the current situation. Ecosystem mapping" (Social Entrepreneurship Association of Latvia, 2018). Let us mention here a few main conclusions of the document regarding the problematic areas. In brief, they are the following: the development of social enterprises is hindered by the lack of business skills among entrepreneurs and the high level dependence on the European financing and various grants; all in all, many entrepreneurs view their companies by analogy with NGOs and charity organizations, whereas by definition the social entrepreneurship is a merger of business and social goals. In addition, it is important to mention that there is no clear understanding about goals of the social enterprises among the general public.

The European Commision report "A map of social enterprises and their eco-systems in Europe, Country Report" (2015) contains a valuable information about Latvia as well. Summarizing these publications, we can see that the social entrepreneurship in Latvia is driven by external forces rather than developed domestically, so in this context the discussion is not about opportunities and problems of social entrepreneurship development, but rather about adaptation of the already existing models. The Social Enterprise Law of Latvia was adopted in 2018 (Legal Acts of the Republıc of Latvia, 2017). The Law defines the social enterpreneurship and its place in the Latvian business environment, as well as the process of asignig the according status. The adoption of the Law facilitated the fast development of this enterpreneurship form - there are up to 200 legal entities that could be considered de facto social enterprises, yet a precise number is unknown. Most social enterprises are relatively new, having been established only within the last 2 to 5 years, and usually do not employ more than 10 people.

The enterpreneurs and other organizations who consider themselves to be socially oriented are united in the "Social Enterpreneurship Association of Latvia". The goals of this association are to advocate enterpreneurs' interests at at local, regional and national levels, to create a common platform and enhance capacities of the members, as well as to inform society about the social enterpreneurship (SEAL, 2018).

Thinking about future of the social ebterpreneurship it is important to educate futre enterpreneurs - business students instilling in them beliefs about what is right and what is wrong and about the social importance of their future venture (Yujuico, 2008).

The aim of the current research is to identify social enterpreneurship intentions among business students in Latvia. To reach the aim the following tasks were set: (1) to accomplish analysis of special literature; (2) to work out methodology; (3) to carry out the empirical research; (4) to work out conclusions.

Literature Review

The researchers have showed a keen interest in the realm of social enterpreneurship, here we can mention investigations by Alvord and others (2004), Austin and others (2006), Dacin and others (2011), Dees \& Anderson (2006), Mair \& Noboa (2006), Seelosa \& Mair (2005), Shina \& Titko (2017) and others. According to some researchers, the social entrepreneurship development is influenced by the three main factors - the demand (public desire for social services/products, as customer or user), the supply (social entrepreneurs) and third - because of the environment and institutional factor that influence the previous two factors (Sekliuckiene \& Kisielius, 2015). Despite the interest in the subject, there is no agreement regarding the definition and scope of it (Dobele, 2013). If in one case it is extremely broad (e.g. EU policies), then in another - it regards particular industry. The same goes for the legal framework. In order to come to some common denominator, we should distinguish three related elements: social entrepreneur (subject), social entrepreneurship (process), social enterprise (object). To describe social entrepreneurship as 
a process, the definition of Yunus (2007) is often used. According to him, social business is a financially sustainable organization created to solve a social problem. First and foremost, it is a business, though socially orientated, directed towards the social impact. A social business has products, services, customers, markets, expenses, and a revenue like a regular busines, it is noloss, no-dividend, self-sustaining company that repays its owners' investment. It is not a charity, but a business in every sense. The European Commission uses the term 'social enterprise' to cover the following types of business:

" Those for who the social or societal objective of the common good is the reason for the commercial activity, often in the form of a high level of social innovation;

» Those whose profits are mainly reinvested to achieve this social objective;

" Those where the method of organisation or the ownership system reflects the enterprise's mission, using democratic or participatory principles or focusing on social justice (European Commission, 2018).

Since the current research is devoted to the business students attitude to social enterpreneurship, it is necessary to understand the enterpreneurship intention formation process. In our investigation, when developing questions for our survey, we employ the intention formation model provided by J. Mair and E. Noboa (2006), that presupposes such elements as desirability, moral judgement, personality characteristics and possibility of financial support. Empirical studies in this field have been carried out by C. Bazan and others (2020) F. M. Alsaatay and others (2014), A. I. Sutha \& P. Sankar (2016), Andriyansah \& Zahra (2017), N. J. Setiadi \& M. Puspitari (2014), S. Ashour (2016) and many others. Despite the fact that forementioned articles have had different research focus, they all stress necessity of students' education in the field of social enterpreneurship.

This study adopted a quantitative research approach because the study involved conducting some statistical analyses to interpret data collected from the respondents. With the aim of identifying social entrepreneurship intentions among business students in Latvia, the target population for the study comprised business administration students of three private universities. The sample consisted of the undergraduate, graduate students and doctoral students registered at the designated institutions for the 2020/2021 academic year; 171 questionnaires were filled out, 167 of them were recognized as valid. The questionnaire was administred in Latvian, thus international students were not included. It was done deliberately, since the study was conducted against the background of the Latvian business environment. This study employed a convenience sampling technique because it tends to be more cost effective and convenient compared to probability sampling techniques (Ghauri et. al., 2020; Malhotra, 2017). Convenience sampling is a non-probability sampling technique where elements of a sample are obtained as a result of availability. The elements in this case happen to be in the right place and at the right time convenient to the researcher. Respondents were students attending classes taught by the authors of the article. The questionnaires were administred administered during classes via Google Forms. The students were informed that their results would be confidential and that the filling out questionnaire was strictly voluntary affair, no bearing any impact on their grades int he respective subjec whatsoever. The questionnaire contained two types of questions - first, statements to be evaluated according to the Likert scale (fully disagree -1; fully agree -5); second - multiple choice questions with two options - to check a single box or to check several boxes). Prior to the main survey a pilot survey was conducted ( $n=20)$, after that some of the question formulations were changed to fitt better to the research design and to be more comprehensible by students (wording of statements).

The questionnaire consisted of 35 items divided in 6 blocks (A - F) (see Table 1). 
Table 1

Summary of questionnaire design

Source: Authors'.

\section{Table 2}

Circular options for furniture sorted according to the EU waste management hierarchy

Source: Authors'.

\begin{tabular}{l|c|l}
\hline \multicolumn{1}{c|}{ Sections of questionnaire } & Item codes & \multicolumn{1}{c}{ Measurement } \\
\hline Demographic profile & A1 - A3 & $\begin{array}{l}\text { Multiple choice questions (1 answer to } \\
\text { be selected) }\end{array}$ \\
\hline Social goals of entrepreneurship & B1- B4 & 5-point Likert scale \\
\hline Intention to engage in social entrepreneurship & C1 - C4 & 5-point Likert scale \\
\hline $\begin{array}{l}\text { Attitude to possible engagement in social } \\
\text { entrepreneurship }\end{array}$ & D1 - D6 & 5-point Likert scale \\
\hline Characteristics of a social entrepreneur & E1 - E7 & 5-point Likert scale \\
\hline Challenges faced by the social entrepreneur & F1 - F11 & $\begin{array}{l}\text { Multiple choice questions (several an- } \\
\text { swers can be selected) }\end{array}$ \\
\hline
\end{tabular}

The first section (A) contained questions related to the socio-demographic profile of the respondents, that is, gender, study level (college, bachelor, master or doctoral) and work experience (see Table 2).

\begin{tabular}{|c|c|c|c|c|c|c|c|c|c|}
\hline \multicolumn{2}{|c|}{ Total, \% } & \multicolumn{4}{|c|}{ Education level (\% of group) } & \multicolumn{3}{c|}{ Work experience in years (\% of group) } \\
\hline & College & Bachelor & Master & Doctoral & 0 & $1-4$ & $5-10$ & $10>$ \\
\hline W & 73 & 27.4 & 55.6 & 16.1 & 0.8 & 13.7 & 43.5 & 21.8 & 21.0 \\
\hline M & 27 & 38.3 & 29.8 & 31.9 & - & 17.0 & 48.9 & 14.9 & 19.1 \\
\hline
\end{tabular}

As it can be seen from the table, the majority of the respondents are studying in the bachelor program, as well as the majority has work experience of 1-4 years, among the respondents $73 \%$ were women, $27 \%$ - men. The age factor of the respondents was not taken into account since they all are students.

The section B of the questionnaire comprised statements regarding students' perception of the social goals of enterpreneurship in general. The statements to be evaluated by 5 -point Likert scale was the following: B1 - „The operation of socially oriented companies is very important for society“; B2 - „From a societal perspective, the social goals of entrepreneurship are more important than making a profit"; B3 - „The main purpose of the business is to make a profit“; B4 - „The goal of business is both profit and the solution of social problems".

The section $\mathrm{C}$, in its turn, was devoted to the students' intention to engage in the social business (to be evaluated according to the 5-point Likert scale). The statements included: C1 - „I plan to start my own business in the next 5 years to meet the needs of society“; C2 - „I plan to start my own business with the aim to meet the needs of the society“; $C_{4}$ - „I am ready to start a business with the aim of meeting the needs of society“; C5 - „I do not plan to get involved in social entrepreneurship."

The section D regarded the students' attitude towrds social enterpreneurship carrerwise (to be evaluated according to the Likert scale): D1 - „I think social entrepreneurship could contribute to my career“; D2 - „I think I could get support to start my dream project“; D3 - „I think my innovative project will change society“; D4 - „I think we need to start a business first, then focus on social projects“; D5 - „If I started a business, my goal would be to help people“; D6 - „ As an entrepreneur, I would support social entrepreneurs financially or otherwise." 
The section E statements (to evaluated according to 5-point Likert scale) were designed to know students opinion about the caracteristic features of an socially responsible enterpreneur. Namely, the enterpreneur: E1 - offers innovative solutions; E2 - is socially responsible; E3 - is ready to take risks; E4 - is ambitious; E5 - is strategically minded; E6 - has imagination; E7 - is focused on the end result.

The sectio F containes the multiple answer possibilities (the respondents could check any number of boxes) related to the possible challenges enterpreneurs could face. The list included such problematic aspects as: F1 to convice others about own ideas; F2 - to attract funding; F3 working remotely; F4 - recruitment of employees; F5 - fundraising; F6 - obtaining the support of business people; F7 - government support; F8 - product / service quality assurance; F9 - retention of employees; F10 - competition with other social entrepreneurs; F11 - lack or absence of knowledge about social entrepreneurship.

Cronbach's alpha reliability measure was used in this study. Ghauri et. al. (2020) describe Cronbach's alpha as a measure of intercorrelations of items that are used to measure the underlying construct. The result of the measure was $a=81$, that indicates the good internal consistency of the questionnaire.

The results were processed by the means of SPSS. In order to make conclusions about the business students' intentions and attitudes the Mann-Whitney U Test, Kruskal-Wallis Test, KMO and Bartlett's Test were performed. The responses were further processed and analyzed in the Results and discussion section below.

Regarding importance of the socially oriented enterprises (B1) among men and women. Applying the non-parametric Mann-Whitney $\cup$ Test to the data set, it appears that women value the role of social enterprises much higher than men, because Rankw $=85.93>$ Mean RankM $=78.93$ (Fig. 1). However, the test $p=0.356>p o=0.05$, which indicates that the scores of both groups are statistically the same.

The next table represents the students' attitude to the goals of social entrepreneurship (B1- B4) according to work experience criterion. The results of the non-parametric Kruskal-Wallis Test show that the education level of the respondents (Total $=167$ ) influences the assessment of social entrepreneurship social goals and business goal priorities, because for question B2 test $p=$ $0.002<\mathrm{p} 0=0.05$, but for question B3 test $\mathrm{p}=0.014<\mathrm{p} 0=0.05$ (see Table 3 ).

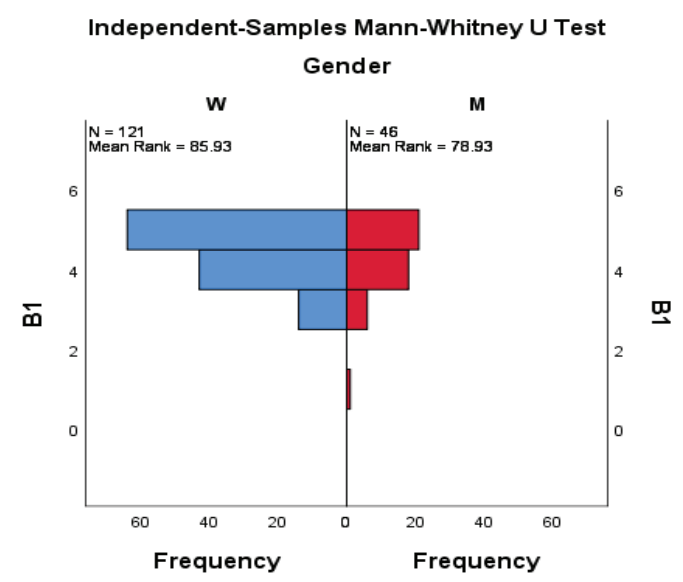

\begin{tabular}{|c|c|c|c|c|c|}
\hline Education & Factor & B1 & B2 & B3 & B4 \\
\hline \multirow{3}{*}{ Test Statistics } & Kruskal-Wallis H & 1.832 & 14.641 & 10.655 & 5.278 \\
\hline & $\mathrm{df}$ & 3 & 3 & 3 & 3 \\
\hline & Asymp. Sig. & .608 & .002 & .014 & .153 \\
\hline
\end{tabular}

a. Kruskal Wallis Test; b. Grouping Variable: Education
Results and discussion

\section{Figure 1}

Mann-Whitney U Test results for the set of answers to question B1Are the activities of socially oriented companies very important for society? (Source: Authors'.)

\section{Table 3}

Kruskal-Wallis Test (nonparametric- 2 independent samples). Test results by gender criterion for set of answers to questions $\mathrm{B} 1$, B2, B3, B4 (evaluation of goals of social business)

Source: Authors'. 
Table 4

Kruskal-Wallis Test (nonparametric- 2 independent samples). Test results by criterion education for the set of answers to questions $\mathrm{C} 1, \mathrm{C} 2, \mathrm{C} 3$, C4 (entrepreneurship intentions)

Source: Authors'.

Table 5

Kruskal-Wallis Test (nonparametric- 2 independent samples). Test results by criterion education for the set of answers to questions D1, D2, D3, D4, D5, D6 (attitude to possible engagement in social entrepreneurship)

Source: Authors'.

\section{Table 6}

Kruskal-Wallis Test (nonparametric- 2 independent samples). Test results by criterion work experience (years) for set of answers to questions D1, D2, D3, D4, D5, D6 (attitude to possible engagement in social entrepreneurship)

Source: Authors'.
The results regarding students' intention to engage in the socially oriented business according to the education criterion (C1-C4) is depicted in the Table 4.

Conclusion: Education does not affect the desire to engage in social entrepreneurship, because in all groups of answers pt> po $=0.05$.

\begin{tabular}{|c|c|c|c|c|c|}
\hline Education & Factor & $\mathrm{C} 1$ & C2 & $\mathrm{C} 3$ & $\mathrm{C} 4$ \\
\hline \multirow{3}{*}{ Test Statistics ${ }^{a, b}$} & Kruskal-Wallis H & 1,082 & 3,543 & 2,989 & 2,533 \\
\hline & $d f$ & 3 & 3 & 3 & 3 \\
\hline & Asymp. Sig. & .781 & .315 & .393 & .469 \\
\hline
\end{tabular}

a. Kruskal Wallis Test; b. Grouping Variable: Education

Table 5 represents students' attitude to their possible engagement in the social entrepreneurship, taking into account the criterion of education.

Conclusion: Education level influences the connection of personal career with social entrepreneurship, but does not affect the desire to get involved in solving social problems important to society.

\begin{tabular}{|c|c|c|c|c|c|c|c|}
\hline Education & Factor & D1 & D2 & D3 & D4 & D5 & D6 \\
\hline \multirow{3}{*}{ Test Statistics } & Kruskal-Wallis H & 9.849 & 3.524 & 3.697 & 3.840 & 5.438 & 4.575 \\
\hline & $d f$ & 3 & 3 & 3 & 3 & 3 & 3 \\
\hline & Asymp. Sig. & .002 & .318 & .296 & .279 & .142 & .206 \\
\hline
\end{tabular}

a. Kruskal Wallis Test; b. Grouping Variable: Education

Correlation between students' attitudes towards socially oriented business and their respective work experience is depicted in the Table 6.

Conclusion: work experience (in years) influences the connection of personal career with social entrepreneurship, but does not affect the desire to get involved in solving social problems important to society.

\begin{tabular}{|c|c|c|c|c|c|c|c|}
\hline Education & Factor & D1 & D2 & D3 & D4 & D5 & D6 \\
\hline \multirow{3}{*}{ Test Statistics $\mathrm{a}, \mathrm{b}$} & Kruskal-Wallis H & 2,864 & 6,722 & 7,579 & 7,294 & 5,091 & 1,715 \\
\hline & $d f$ & 3 & 3 & 3 & 3 & 3 & 3 \\
\hline & Asymp. Sig. & .413 & .081 & .056 & .063 & .165 & .634 \\
\hline
\end{tabular}

a. Kruskal Wallis Test; b. Grouping Variable: Work experience

After that the factor analysis was used to reduce the number of factors D1-D6 and to determine the interrelationships of several variables. Bartlett's Test of Sphericity Test was performed, which shows that the data are valid for factor analysis, because $p=0.000<p o=0.05$. The principal axis factoring method was used to obtain factors from the data set, but the Varimax method was used for factor rotation. Assessing the factor loads, it can be seen that the respondent's goals are characterized by 2 groups of factors (Fig. 2): 


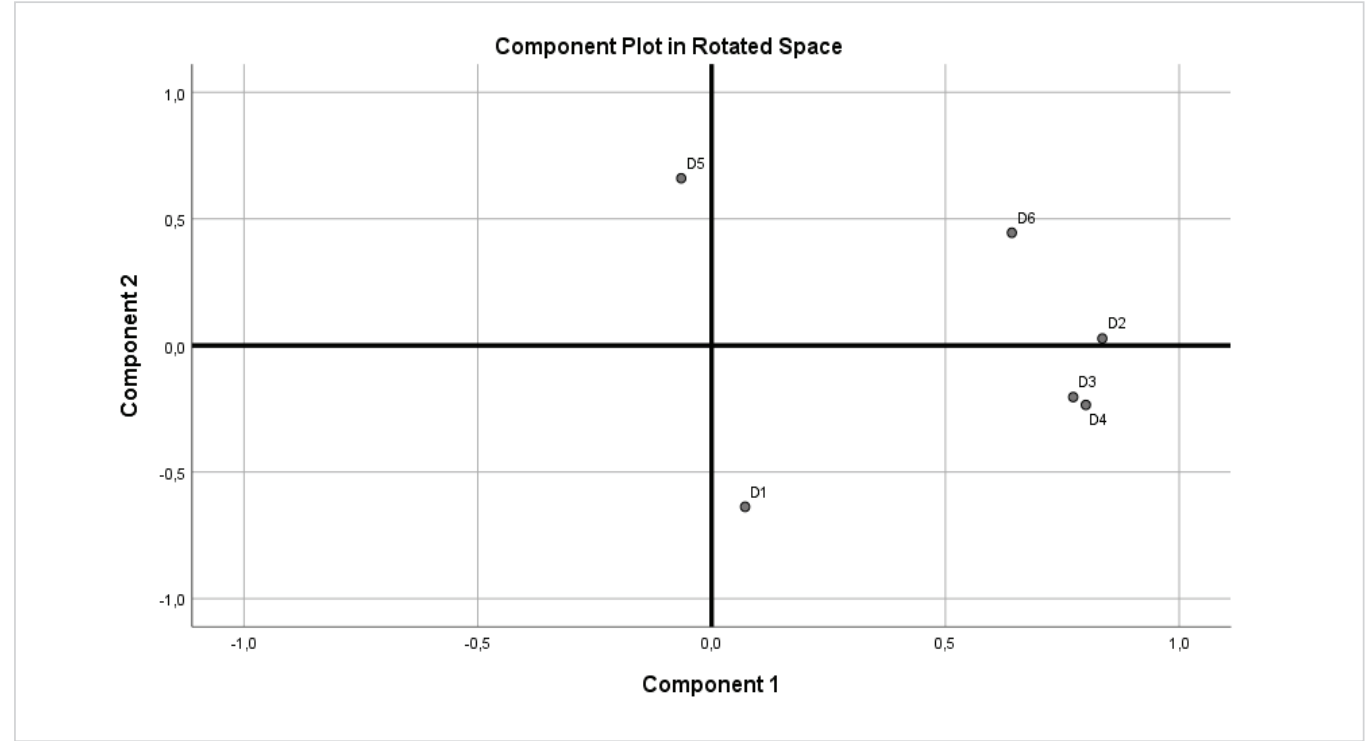

1 Component 1 - factors that characterize the respondents' goal of engaging in social entrepreneurship to promote the socio-economic growth of society. The group includes factors D2, D4, D3, D6;

2 Component 2 - factors that characterize the respondents' subjective goals. The group includes factors D5 and D1.

As it can be seen in the Figure 2, the first component is mostly correlated with factors D2 (possible support for starting dream project), D4 (starting business first, after that engaging in social entrepreneurship) and D3 (impact of innovative projects on society). At the same time the second component is mostly correlated with factor D5 (personal intention to engage in social business). I is important to note that students do not see socially oriented business as means for advancement of their future career (D1), whereas placement of factor D6 demonstrates that students have a strong intention to support social initiatives in future.

The aim of the current research was to identify Latvian business students' intention to engage in the social entrepreneurship, taking into account the significance of the urgency of the matter in the today's world riddled by economic crises. In order to that the students' survey using 5-point Likert scale was carried out (167 questionnaires were recognized as valid). The survey contained questions regarding students' socio-demographic profile (age, education and work experience), general attitude towards social business, intention to engage in social entrepreneurship, attitude to possible engagement in social entrepreneurship, characteristics of a social entrepreneur, challenges faced by the social entrepreneur. To process results the statistical (non-parametric) tests were performed. The main results can be summed up as follows:

» Applying the non-parametric Mann-Whitney U Test to the data set, it appears that women value the role of social enterprises much higher than men;

" The results of the non-parametric Kruskal-Wallis Test show that the education level of the respondents influences the assessment of social entrepreneurship social goals and business goal priorities;

"At the same time, it has to be concluded that education does not affect the desire to engage in social entrepreneurship, because in all groups of answers $\mathrm{pt}>\mathrm{po}=0.05$;
Figure 2

Factor analysis results for data D1-D6 after factor rotation (Source: Authors'.) 
"Education level influences the connection of personal career with social entrepreneurship, but does not affect the desire to get involved in solving social problems important to society;

"As to impact of work experience, it can be concluded that work experience (in years) influences the connection of personal career with social entrepreneurship, but does not affect the desire to get involved in solving social problems important to society;

» Factor analysis demonstrates that the first component (factors that characterize the respondents' goal of engaging in social entrepreneurship to promote the socio-economic growth of society) is mostly correlated with possible support for starting dream project), starting business first, only after that engaging in social entrepreneurship and belief impact of innovative projects on society. At the same time the second component (respondents' subjective goals) is mostly correlated with personal intention to engage in social business. I is important to note that students do not see socially oriented business as means for advancement of their future career, whereas they express their intent to support (financially or in other ways) social entrepreneurship in future.

The results obtained in the current investigation point at the future research directions, namely, the ones related to educational aspects (teaching; development of personality traits, instilling societal values, etc.).

\section{References}

Alsaaty F. M., Abrahams, D. \& and Carter, E. (2014). Business Students' Interests in Entrepreneurship and Social Entrepreneurship at a Historically Black Institution. Journal of Small Business and Entrepreneurship Development, 2(1), 1-30.

Alvord, S. H., Brown, L. D., \& Letts, C. W. (2004). Social Entrepreneurship and Societal Transformation an Exploratory Study. The journal of applied behavioral science, 40(3), 260-282, https://doi. org/10.1177/0021886304266847

Andriyansah \& Zahra, F. (2017). Student awareness towards social entrepreneurship: A qualitative study. International Journal of Civil Engineering and Technology, 8, 457-464.

Ashour, S. (2016). Social and business entrepreneurship as career options for university students in the United Arab Emirates: The drive-preparedness gap. Cogent Education, 3(1), 1234425, https://doi.org/10.1 080/2331186X.2016.1234425

Austin, J., Stevenson. H., \& Wei-Skillern, J. (2006). Social and Commercial Entrepreneurship: Same, Different, or Both? Enterpreneurship: Theory and Practice, 30(1), 1-22, https://doi.org/10.1111/j.15406520.2006.00107.x

Bazan C. et al. (2020). Effect of the university on the social entrepreneurial intention of students. New England Journal of Entrepreneurship, 23(1), 3-24, https://doi.org/10.1108/NEJE-05-2019-0026

Dacin, M. T., Dacin, P. A., \& Tracey, P. (2011). Social Entrepreneurship: A Critique and Future Directions. Organization Science, 22(5), 1203-1213, https://doi. org/10.2307/41303113 https://doi.org/10.1287/ orsc. 1100.0620

Dees, J. G., Anderson, B. B. (2006). Framing a Theory of Social Entrepreneurship: Building on Two schools of Practice and Thought. Research on Social Entrepreneurship: Understanding and Contributing to an Emerging field, 1(3), 39-66.

Dobele, L. (2013). Sociālās uzṇēmējdarbības attīstības iespējas Latvijā. Retrieved 22 March, 2021 from http://llufb.llu.lv/dissertation-summary/entrepreneurship/LasmaDobele_promoc_d_kopsavilkums_2014_LLU_ESAF.pdf

European Commission. (2015). A map of social enterprises and their eco-systems in Europe, Country Report: Latvia. Retrieved 10 March, 2021 from http:// www.lm.gov.lv/upload/darbs_eng/se_mapping_ country_report_latvia.pdf

European Commission. (2018). Social economy in the EU. Retrieved from 20,March, 2021 from https:// ec.europa.eu/growth/sectors/social-economy/enterprises_en

Ghauri P., Gronhaug K. \& Strange R. (2020). Research methods in business studies (p. 350). Cambridge, UK: Cambridge University Press https://doi. org/10.1017/9781108762427

Legal Acts of the Republic of Latvia. (2017). Social Enterprise Law. Retrieved 20 February, 2021 from https://likumi.lv/ta/en/en/id/294484

Lešinska, A. et al. (2012). Latvija ceḷā uz sociālo uzṇēmējdarbību. Retrieved 10 March, 2021 from http://providus.lv/article_files/2265/original/SU_ gala_9nov.pdf?1352889758 
Līcīte, L. (2018). Social enterprises and their ecosystems in Europe. Country report LATVIA. Retrieved 1, March, 2021 from https://sua.lv/wp-content/uploads/2018/12/Social-enterprises-and-their-ecosystems-in-Europe.-Country-report-Latvia.pdf

Lukjanska, R., Kuznecova, J., \& Cirule, I. (2017). The development of social entrepreneurship in Latvia: the role of municipalities. International Journal of Business and Globalization, 18(3), 318 - 336. https://doi. org/10.1504/IJBG.2017.083206

Mair, J. \& Noboa, E. (2006). Social entrepreneurship: How intentions to create a social venture are formed. In J. Mair, J. Robinson and K. Hockerts (Eds.), Social entrepreneurship (pp. 121-135). Houndmills, Basingstoke: Palgrave Macmillan UK. https://doi. org/10.1057/9780230625655

Malhotra N. K., Nunan D. \& Birks D. F. (2017). Marketing research. An applied approach (p. 976). Harlow: Pearson Education Limited.

Sannikova, \& A., Brante, I. (2018). Development of Social Entrepreneurship in Latvia. Business. Management and Education, 16(1), 147-159, https://doi. org/10.3846/bme.2018.2198

SEAL. (2018). Social entrepreneurship in Latvia: a brief overview of the current situation. Ecosystem mapping. Retrieved 12 March, 2021 from https:// sua.lv/wp-content/uploads/2019/04/LSUA_report_2-ENG.pdf

Seelosa, C. \& Mair, J. (2005). Social entrepreneurship:
Creating new business models to serve the poor. Business Horizons, 48, 241-246 https://doi.org/ 10.1016/j. bushor.2004.11.006 https://doi.org/10.1016/j.bushor.2004.11.006

Sekliuckiene, J. \& Kisielius, E. (2015). Development of Social Entrepreneurship Initiatives: A Theoretical Framework. Procedia -Social and Behavioral Sciences, (213), 1015-1019, https://doi.org/10.1016/j.sbspro.2015.11.519

Setiadi, N. J. \& Puspitasari, D. M. (2014). Empirical study of entrepreneurial attitudes and intentions among Indonesian business students. DLSL Journal of Management, 1(1), 145-162.

Shina, I., Titko, J. (2017). Social Entrepreneurship Development Factors in Europe. Proceedings of the 2017 International Conference "ECONOMIC SCIENCE FOR RURAL DEVELOPMENT", 46 Jelgava, LLU ESAF, 27-28 April 2017, 158-165.

Sutha, I. \& Sankar, P. (2016). Entrepreneurial Intention and Social Entrepreneurship among University Students in Chennai City. International Journal of Engineering Studies, 8(1), 93-106.

Yujuico, E. (2008). Connecting the Dots in Social Entrepreneurship through the Capabilities Approach. Socio-Economic Review, 6(3), 493-513, https://doi. org/10.1093/ser/mwn003

Yunus M. (2008). Creating the World Without Poverty. Social Business and the Future of Capitalism (p. 297). New York: Public Affairs.

\section{VEVERE VELGA}

Dr. phil.

EKA University of Applied Sciences

\section{Fields of interests}

Critical thinking, corporate social responsibility, business ethics, corporate governance, marketing communications.

\section{Address}

1/5 Lomonosova street, Riga LV1003, Latvia,

+37126463584

velga.vevere@gmail.com

\section{CERKOVSKIS EDGARS}

MBA

EKA University of Applied

Sciences

Fields of interests

Regional economics, digital means in business studies, social entrepreneurship, circular economy.
Address
1/ Lomonosova street, Riga
LV-1003, Latvia,
+371 26136998
e.cerkovskis@gmail.com

\section{SANNIKOVA AIJA}

Dr.oec.

EKA University of Applied

Sciences

\section{Fields of interests}

Statistics, social entrepreneurship, circular economy.

\section{Address}

1/5 Lomonosova street, Riga LV 1019, Latvia.

aija.sannikova@inbox.lv
About the authors 